\title{
The nutritive value of fat in the diet of the milk-fed lamb
}

\section{2.* The effect of different dietary fats on the composition of the body fats}

\author{
BY G. B. STOKES† AND D. M. WALKER \\ Department of Animal Husbandry, University of Sydney, Australia
}

(Received I8 fuly 1969-Accepted 5 November 1969)

\begin{abstract}
x. The fatty acid composition of the depot fats of thirty-six preruminant lambs was determined. Four lambs were slaughtered at $3 \mathrm{~d}$ of age, two lambs were fed on a low-fat diet for $28 \mathrm{~d}$, and thirty lambs in groups of three were given ten different dietary fats in artificialmilk diets for $28 \mathrm{~d}$.

2. The fatty acid patterns of the carcass fats were closely related to those of the dietary fats, and within-treatment variations were extremely low. Significant differences in fatty acid composition were observed between the skin, carcass, perinephric and subcutaneous lipids, irrespective of the diet given.

3. The carcass lipids of lambs given the low-fat diet were similar in their fatty acid composition to those of lambs aged $3 \mathrm{~d}$, though the former lambs lost fat from the carcass during the experimental period.
\end{abstract}

Hoflund, Holmberg \& Sellman (1956) and Erwin \& Sterner (I963) have demonstrated that the fatty acid composition of the depot fats of preruminant calves, unlike those of the adult, may be extensively modified by variations in the composition of the dietary fat. No comparable data are available for preruminant lambs, though Body \& Shorland (1964) and Downing (1964) have given values for the fatty acid composition of the lipids of the foetal lamb and of the newly born lamb, respectively. The depot fats in both groups contained a high proportion of unsaturated fatty acids.

The aims of the present experiment were to determine to what extent the fatty acid composition of the depot fats of preruminant lambs could be altered by feeding different dietary fats; and to determine whether there were significant differences in the composition of the depot fats in different parts of the body.

\section{EXPERIMENTAL}

The samples of depot fats used in this experiment were obtained from eleven groups of male cross-bred lambs ((Border Leicester $\delta \times$ Merino $q) \times$ Dorset Horn $\delta)$ whose feeding, management and performance have already been described (Walker $\&$ Stokes, 1970). Four lambs (initial group) were slaughtered after they had suckled the ewe for $3 \mathrm{~d}$. The fatty acid compositions of the carcass, perinephric, subcutaneous and skin lipids are reported for the initial group and for groups receiving diets $\mathrm{A}-\mathrm{E}$ and $\mathrm{K}$, and of the carcass lipids only for lambs receiving diets F-J.

* Paper no. I: Br. $\mathscr{~}$. Nutr. (1970), 24, 425.

$\uparrow$ Present address: Department of Biochemistry, N. Carolina State University, Raleigh, NC, USA. 


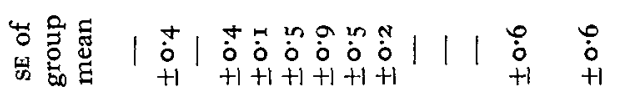

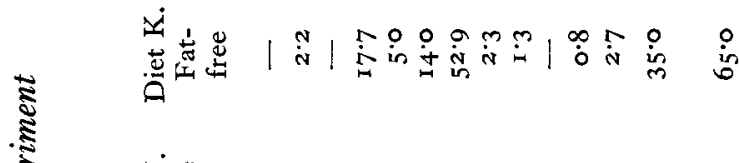

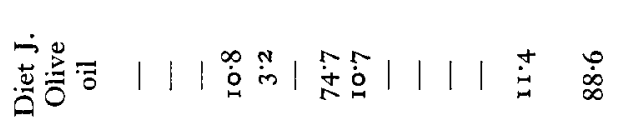

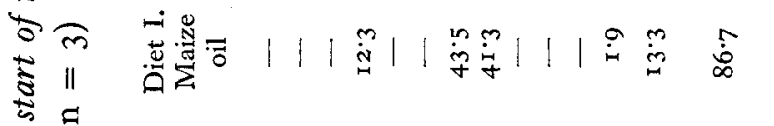

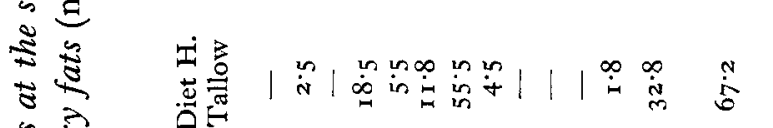

हो मी है

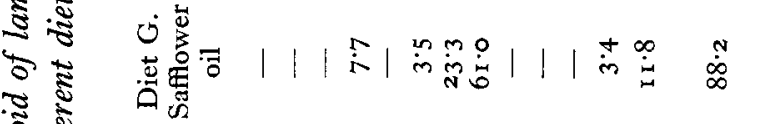

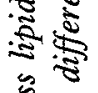

है

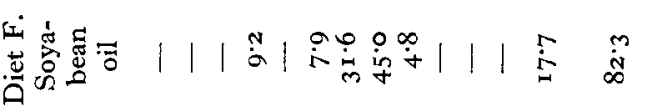

₹ 11

고

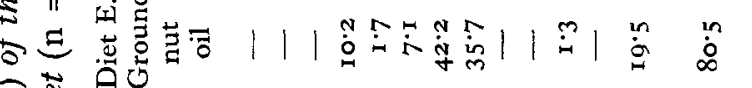

की:

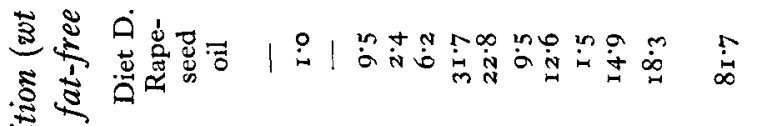

空.

उ

窎

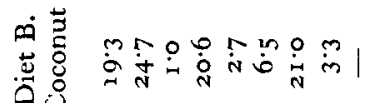

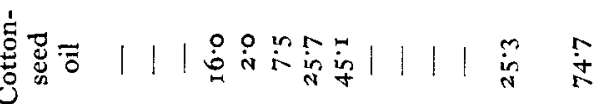

i.

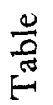

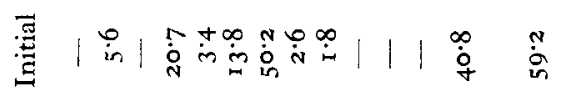

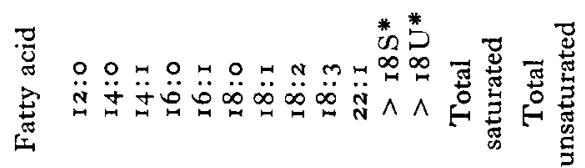




\section{Analytical methods}

The methods used for the extraction of the lipids, and for the preparation and separation of the fatty acid methyl esters, were as described for faeces (Walker \& Stokes, 1970), but without prior acidification.

\section{RESULTS}

Distribution of body fat. The major fat depot of the lambs was the carcass, which contained approximately $88 \%$ of the total body fat in groups receiving diets $\mathrm{A}-\mathrm{C}$ and E-J (carcass fat including perinephric and subcutaneous fat, $386 \pm 22 \mathrm{~g} ; 87.9 \pm 0.6 \%$; $n=25$ ). The lambs given diets $\mathrm{D}$ and $\mathrm{K}$ lost body fat during the experimental period, as estimated by comparative slaughter methods, and there was a relatively greater loss of fat from the carcass than from the skin and wool. In groups receiving diets $\mathrm{A}-\mathrm{C}$ and E-J the skin contained $7 \cdot 5 \pm 0.4 \%$ of the total body fat and the wool $4 \cdot 6 \pm 0.3 \%$. The corresponding values for the lambs given diets $\mathrm{D}$ and $\mathrm{K}(n=5)$, were: carcass fat, I $16 \pm 28 \mathrm{~g}, 72 \cdot 0 \pm 6 \cdot 3 \%$; skin fat, $13 \cdot 0 \pm 3 \cdot \circ \%$; wool fat, $15 \cdot 0 \pm 3 \cdot 5 \%$. Subcutaneous and perinephric fats made only a small contribution to the total body fat $(c .1 \cdot 0$ and $3.5 \%$, respectively) in all groups.

Table 2. Mean fatty acid composition (wt \%) of the skin lipids of lambs given a fat-free diet $(\mathrm{n}=2)$, or different dietary fats $(\mathrm{n}=3)$

\begin{tabular}{|c|c|c|c|c|c|c|}
\hline Fatty acid & $\begin{array}{c}\text { Diet A. } \\
\text { Lard }\end{array}$ & $\begin{array}{l}\text { Diet B. } \\
\text { Coconut }\end{array}$ & $\begin{array}{c}\text { Diet C. } \\
\text { Cottonseed } \\
\text { oil }\end{array}$ & $\begin{array}{l}\text { Diet D. } \\
\text { Rapeseed } \\
\text { oil }\end{array}$ & $\begin{array}{c}\text { Diet E. } \\
\text { Groundnut } \\
\text { oil }\end{array}$ & $\begin{array}{l}\text { Diet K. } \\
\text { Fat-free }\end{array}$ \\
\hline $12: 0$ & - & 19.8 & - & 一 & - & - \\
\hline $14: 0$ & $2 \cdot 0$ & $21 \cdot 0$ & $I \cdot 5$ & $I \cdot 7$ & I.8 & $2 \cdot 6$ \\
\hline $14: 1$ & $1 \cdot 2$ & $2 \cdot 4$ & $\mathrm{I} \cdot 0$ & $\mathrm{I} \cdot 8$ & $2 \cdot 1$ & $3 \cdot 3$ \\
\hline $16: 0$ & $20 \cdot 3$ & $19 \cdot 2$ & $16 \cdot 4$ & $12 \cdot 2$ & 14.4 & $12 \cdot 6$ \\
\hline $16: 1$ & $7 \cdot 8$ & 5.0 & $4 \cdot I$ & $5 \cdot 0$ & $3 \cdot 9$ & $7 \cdot 5$ \\
\hline $18: 0$ & $9 \cdot 0$ & $4 \cdot 8$ & $7 \cdot 5$ & $5 \cdot 6$ & $7 \cdot 4$ & $5 \cdot 8$ \\
\hline $18: 1$ & $46 \cdot 5$ & 20.5 & 24.5 & $26 \cdot 6$ & $36 \cdot 8$ & $32 \cdot 2$ \\
\hline $18: 2$ & $8 \cdot 0$ & $3 \cdot 6$ & $29 \cdot 8$ & $12 \cdot 6$ & $23 \cdot 3$ & $2 \cdot 0$ \\
\hline $18: 3$ & - & - & - & $5 \cdot 2$ & - & - \\
\hline $\begin{array}{l}\text { Total } \\
\text { branched }\end{array}$ & $x \cdot 7$ & - & $I \cdot 5$ & $2 \cdot 3$ & $2 \cdot 0$ & $6 \cdot 2$ \\
\hline$>\mathrm{I} 8 \mathrm{~S}^{*}$ & - & - & $2 \cdot 0$ & $8 \cdot \mathrm{I}$ & - & $2 \cdot 8$ \\
\hline$>\mathrm{I} 8 \mathrm{U}^{*}$ & $2 \cdot 9$ & $2 \cdot 4$ & 10.2 & 17.8 & $6 \cdot 3$ & $22 \cdot 5$ \\
\hline $\begin{array}{c}\text { Total } \\
\text { saturated }\end{array}$ & $3 \times \cdot 7$ & $65 \cdot 5$ & 27.8 & $28 \cdot 2$ & 24.4 & $24 \cdot 5$ \\
\hline $\begin{array}{c}\text { Total } \\
\text { unsaturated }\end{array}$ & $68 \cdot 3$ & 34.5 & $72 \cdot 2$ & $7 \mathrm{I} \cdot 8$ & $75 \cdot 6$ & 75.5 \\
\hline
\end{tabular}

* $>18 \mathrm{~S}, 18 \mathrm{U}=$ concentration of saturated and unsaturated fatty acids with greater than eighteen carbon atoms.

\section{Fatty acid composition of depot fats}

The tables of fatty acid compositions given in this paper include only the major constituents, comprising $>\mathrm{I} \%$. The minor constituents and fatty acids occurring only in traces have been omitted, to facilitate comparisons between dietary and tissue lipids. 
The fatty acid compositions of the dietary fats and oils were given in the preceding paper (cf. Table 3 ; Walker \& Stokes, 1970 ). Mean values for the fatty acid compositions of the separate depot fats are given in Tables $1-4$. Although the skin fat contained a wider range of fatty acids than the other depot fats, the majority were present in concentrations of less than $\mathrm{I} \%$, and are not listed in Table 2 .

The lambs receiving diet $\mathrm{K}$, the low-fat diet of reconstituted dried skim milk,

Table 3. Mean fatty acid composition (wt \%) of the perinephric lipids of lambs at the start of the experiment $(\mathrm{n}=4)$, or given a fat-free diet $(\mathrm{n}=2)$, or different dietary fats $(\mathrm{n}=3)$

\begin{tabular}{|c|c|c|c|c|c|c|c|}
\hline Fatty acid & Initial & $\begin{array}{l}\text { Diet A. } \\
\text { Lard }\end{array}$ & $\begin{array}{l}\text { Diet B. } \\
\text { Coconut }\end{array}$ & $\begin{array}{l}\text { Cottonseed } \\
\text { oil }\end{array}$ & $\begin{array}{c}\text { Rapeseed } \\
\text { oil }\end{array}$ & $\begin{array}{l}\text { Groundnut } \\
\text { oil }\end{array}$ & $\begin{array}{l}\text { Diet K. } \\
\text { Fat-free }\end{array}$ \\
\hline $12: 0$ & - & - & $17 \cdot 3$ & - & - & - & - \\
\hline $14: 0$ & $4 \cdot 2$ & $1 \cdot 2$ & $29 \cdot 6$ & - & - & - & $1 \cdot 2$ \\
\hline $16: 0$ & 17.9 & $17 \cdot 6$ & $20 \cdot 2$ & $12 \cdot 3$ & $4 \cdot 4$ & $8 \cdot 5$ & 13.7 \\
\hline $16: 1$ & $2 \cdot 5$ & $3 \cdot 5$ & $1 \cdot 5$ & - & - & - & $2 \cdot 6$ \\
\hline $17: 0$ & $I \cdot I$ & I.O & - & - & - & - & - \\
\hline $18: 0$ & $18 \cdot 3$ & $19 \cdot 9$ & II $\cdot 2$ & 10.6 & 40 & $9 \cdot I$ & $28 \cdot 6$ \\
\hline I $8: x$ & 49.5 & $48 \cdot 6$ & 16.8 & $24 \cdot I$ & $28 \cdot 2$ & $41 \cdot 0$ & $46 \cdot 9$ \\
\hline $18: 2$ & $2 \cdot 4$ & $6 \cdot 0$ & $1 \cdot 9$ & $49^{\circ} \cdot$ & $26 \cdot 2$ & $3^{6} \cdot 9$ & 1.7 \\
\hline $18: 3$ & $x \cdot 9$ & - & - & I. & $I I \cdot I$ & - & $\therefore$ \\
\hline$>18 \mathrm{~S}^{*}$ & - & - & - & - & - & - & - \\
\hline$>\mathrm{I} 8 \mathrm{U}^{*}$ & - & - & - & - & $24 \cdot 6$ & $1 \cdot 7$ & $3 \cdot I$ \\
\hline $\begin{array}{c}\text { Total } \\
\text { saturated }\end{array}$ & $42 \cdot 4$ & 39.8 & $78 \cdot 7$ & $23 \cdot 3$ & $8 \cdot 8$ & 18.7 & $45^{\cdot 2}$ \\
\hline $\begin{array}{c}\text { Total } \\
\text { unsaturated }\end{array}$ & $57^{\circ} \cdot 6$ & $60 \cdot 2$ & $21 \cdot 3$ & $76 \cdot 7$ & $9 \mathrm{I} \cdot 2$ & $8 r \cdot 3$ & 54.8 \\
\hline
\end{tabular}

* $>18 \mathrm{~S}, \mathrm{I} 8 \mathrm{U}=$ concentration of saturated and unsaturated fatty acids with greater than eighteen carbon atoms.

Table 4. Mean fatty acid composition (wt \%) of the subcutaneous lipids of lambs at the start of the experiment $(\mathrm{n}=4)$, or given a fat-free diet $(\mathrm{n}=2)$, or different dietary fats $(\mathbf{n}=3)$

\begin{tabular}{|c|c|c|c|c|c|c|c|}
\hline Fatty acid & Initial & $\begin{array}{l}\text { Diet A. } \\
\text { Lard }\end{array}$ & $\begin{array}{l}\text { Diet B. } \\
\text { Coconut }\end{array}$ & $\begin{array}{l}\text { Cottonseed } \\
\text { oil }\end{array}$ & $\begin{array}{c}\text { Rapeseed } \\
\text { oil }\end{array}$ & $\begin{array}{l}\text { Groundnut } \\
\text { oil }\end{array}$ & $\begin{array}{l}\text { Diet K. } \\
\text { Fat-free }\end{array}$ \\
\hline $12: 0$ & $I \cdot 2$ & - & $29^{\circ} 0$ & - & - & - & - \\
\hline $14: 0$ & $7 \cdot 2$ & $I \cdot 6$ & $28 \cdot I$ & - & $I \cdot I$ & - & $I \cdot 9$ \\
\hline $16: 0$ & $21 \cdot 7$ & 23.3 & $17 \cdot 7$ & $16 \cdot 2$ & 9.0 & 10.8 & $15 \cdot 2$ \\
\hline $16: 1$ & $3 \cdot 4$ & $4 \cdot 6$ & $1 \cdot 5$ & $1 \cdot 3$ & $r \cdot 9$ & $\mathrm{I} \cdot 4$ & 4.5 \\
\hline $17: 0$ & $1 \cdot 3$ & $1 \cdot 0$ & - & - & - & - & $I \cdot I$ \\
\hline 18:0 & 13.8 & 14.4 & $5 \cdot 3$ & $9 \cdot 0$ & $7 \cdot 7$ & $7 \cdot 9$ & $17 \cdot 3$ \\
\hline $18: 1$ & $45 \cdot 4$ & $48 \cdot 4$ & $15 \% 7$ & $26 \cdot 3$ & 33.7 & $43 \cdot 2$ & 56.4 \\
\hline $18: 2$ & $2 \cdot 2$ & 5.5 & $\mathrm{I} \cdot 8$ & $44 \cdot 7$ & $18 \cdot 5$ & $33 \cdot 3$ & 1.4 \\
\hline I 8:3 & $I \cdot 7$ & - & - & $I \cdot I$ & $5 \cdot 3$ & - & - \\
\hline$>18 \mathrm{~S}^{*}$ & - & - & - & 一 & - & - & - \\
\hline$>18 U^{*}$ & - & - & - & - & $21 \cdot 3$ & $1 \cdot 2$ & - \\
\hline $\begin{array}{c}\text { Total } \\
\text { saturated }\end{array}$ & $45 \cdot 6$ & $40^{\prime} 4$ & $80 \cdot 4$ & $26 \cdot I$ & 19.2 & $19^{\circ} 6$ & $36 \cdot 7$ \\
\hline $\begin{array}{c}\text { Total } \\
\text { unsaturated }\end{array}$ & $54 \% 4$ & $59 \cdot 6$ & $19 \cdot 6$ & $73 \cdot 9$ & $80 \cdot 8$ & $80 \cdot 4$ & $63 \cdot 3$ \\
\hline
\end{tabular}

* $>\mathrm{I} 8 \mathrm{~S}, \mathrm{I} 8 \mathrm{U}=$ concentration of saturated and unsaturated fatty acids with greater than eighteen carbon atoms. 
lost depot fat during the experimental period but, nevertheless, the fatty acid patterns at slaughter were very similar to those of the initial group of lambs. This would suggest that there was little selective withdrawal, or relative accumulation of particular fatty acids, or interconversion between fatty acids.

The fatty acid patterns in the depot fats of lambs given lard, tallow, cottonseed, groundnut, soya-bean, safflower, maize and olive oil reflected the patterns of the respective dietary fats. However, the composition of the depot fats of lambs given rapeseed oil and coconut fat differed from those of the dietary fats. These differences were a reflection of the indigestibility of erucic acid in the rapeseed oil, and of the selective oxidation and chain elongation that had occurred during the metabolism of the coconut fat.

A two-way analysis of variance for each fatty acid, between dietary treatment groups and depot fats, showed that there were highly significant differences between the dietary treatment groups, and between the depot fats regardless of the dietary treatment. The within-treatment variation was extremely low. Thus the proportion of a fatty acid in the dietary fat markedly influenced the proportion of that fatty acid in the depot fat, and each depot had a characteristic pattern of deposition.

Skin lipids. The fatty acids of the skin lipids had significantly greater proportions of $>\mathrm{I} 8 \mathrm{~S}(P<0.00 \mathrm{I})$ and of $>\mathrm{I} 8 \mathrm{U}(P<0.0 \mathrm{I})$, and significantly lower proportions of fatty acids with eighteen carbon atoms $(P<0 \cdot 00 \mathrm{r})$ than any other depot fat.

Branched-chain fatty acids ( $12 \mathrm{br}, 14 \mathrm{br}$ and $16 \mathrm{br}$ ) were found only in the skin lipids, and although the perinephric and subcutaneous lipids contained low concentrations of I $8 \mathrm{br}$, the skin contained significantly greater proportions $(P<0.00 \mathrm{I})$. There was a notable absence of branched-chain fatty acids in the skin lipids of lambs given coconut fat (diet $B)$. The skin lipids also contained significantly greater concentrations of I0:0, I4:I and I6:I $(P<0.001)$ than the other depot lipids.

Carcass lipids. The carcass lipids contained significantly greater proportions of $>$ I $8 \mathrm{~S}$ fatty acids than the perinephric and subcutaneous lipids $(P<0.01)$.

Perinephric and subcutaneous lipids. The perinephric lipids contained significantly greater proportions of $\mathrm{I} 8: 0$ and $\mathrm{I} 8: 2(P<0.00 \mathrm{r})$, and significantly lower proportions of $16: 0$ and $16: 1(P<0.001)$, than the subcutaneous lipids. The ratio of $18: 0$ to I 8: 1 was significantly greater, and those of $16: 0$ to $18: 0$ and $16: 1$ to $18: 1$ were significantly lower $(P<0.00 \mathrm{I})$ in the perinephric lipids than in the subcutaneous lipids.

\section{DISCUSSION}

The lambs at the start of this experiment had very small amounts of depot fat but, during the experimental period of 4 weeks, most lambs doubled their live weight and trebled their content of body fat. This means that about two-thirds of the fat in the lamb at slaughter was derived from the diet, on the assumption that there was no extensive mobilization of the fat that was present initially. The fatty acid patterns of the dietary and depot fats were closely related, in all groups, with the exceptions of the rapeseed oil and coconut-fat diets, where minor differences were noted. Thus, in the preruminant lamb, in contrast to the adult ruminant, the composition of the depot fat 
is largely determined by the composition of the dietary fat and, in the absence of a functional rumen with its associated micro-organisms, no extensive changes of the dietary fatty acids occur before absorption (cf. Garton, I967).

\section{REFERENCES}

Body, D. R. \& Shorland, F. B. (1964). Nature, Lond. 202, 769. Downing, D. T. (1 964). F. Lipid Res. 5, 210.

Erwin, E. S. \& Sterner, W. (1963). Am. F. Physiol. 205, I 5 I.

Garton, G. A. (1967). Wld Rev. Nutr. Diet. 7, 225.

Hoflund, S., Holmberg, J. \& Sellman, G. (I956). Cornell Vet. 46, 51 .

Walker, D. M. \& Stokes, G. B. (1970). Br. F. Nutr. 24, 425. 